\title{
The Impact of Internal Audit Committees' Practices on Enhancing the Independence of Internal Auditors in Jordanian Commercial Banks
}

\author{
Khalil Abu Saleem ${ }^{1}$ \\ ${ }^{1}$ Associate Professor, Accounting Department - Faculty of Business \& Finance, The World Islamic Sciences \& \\ Education University (W.I.S.E), Jordan \\ Correspondence: Khalil Abu Saleem, Associate Professor, Accounting Department - Faculty of Business \& \\ Finance, The World Islamic Sciences \& Education University (W.I.S.E), Jordan. E-mail: \\ kalilabosaleem@yahoo.com
}

Received: February 14, 2018

Accepted: March 14, 2018

Online Published: April 18, 2018

doi:10.5539/ijbm.v13n5p156

URL: https://doi.org/10.5539/ijbm.v13n5p156

\begin{abstract}
Purpose: This study aim to explain the impact of the audit committees' practices on enhancing the independence of internal auditors in Jordanian commercial banks from the perspective of external auditors.

Design / methodology / approach: The statistical descriptive approach was used, the data were collected through a questionnaire designed by the researcher, which targeted the external auditors of (90) individuals. The study included four axes, three of which were allocated to measure the internal audit committees' responsibilities, functions and powers, while the fourth axis was devoted to measuring the independence of the internal auditing bodies.
\end{abstract}

Results: The study found that there is a statistically significant relationship to the internal audit committees' practices in enhancing the independence of the internal auditing bodies; also the role of the audit committees has been the main impact in enhancing this independence.

Recommendations: the study recommends enacting and modifying laws to enhance the independence of the audit committees to supervise all matters related to internal auditors.

Originality / Value: According to the researcher, this study is one of the first studies that dealt with the practices of the audit committees combined, therefore it is useful for researchers that motivating them to conduct further research on the practices of audit committees in other economic sectors.

Keywords: audit committees' practices, independency, commercial banks

\section{Introduction}

Commercial banks are considered an important source of the economy in the modern era through its role in steering the economic wheel for the societies they operate in, because in one hand, they provide funds from various sources and invest them in various economic activities on the other hand.

Therefore, there was a need for a party to monitor the work of these banks in order to ensure the preservation of these funds and protect them from manipulation, fraud and theft, and hence the need for a party that enjoys a certain level of independence from the management of the bank has emerged that works to perform that task, which is called the internal audit function.

As the internal auditor is considered as an employee of the bank's staff, and he is therefore not immune from the interventions of the management of his work, since he is under the authority of this management and executes its instructions as long as he is one of its employees, so there was an urgent need for a party that supports and monitors his work, and provides a kind of protection and independency from the bank's management, so that he can carry out his functions.

To ensure that the internal auditor performs his work efficiently and effectively away from any management interventions, most legislations and laws in different countries of the world, in addition that all bodies and professional complexes have committed and stipulated the necessity of the existence of internal audit committees (IACs) in all banks that enjoy many powers, responsibilities and functions to exercise their job thereby enhancing the independence of the internal auditor. 


\section{Study Importance}

The importance of the study stems from the role that the IACs can perform in providing an appropriate level of independence to the internal audit services that monitor the bank's operations to prevent fraud and mistakes, as well as they are one of the most important parts of the internal control system in commercial banks.

\subsection{Study Problem}

The study problem can be framed by the following main question:

- Do the IACs practices affect on strengthening the independence of the internal audit services in Jordanian commercial banks? The following questions stem from the main question:

1. Do the functions of IACs affect the reinforcement of the independence of the internal audit services in Jordanian commercial banks?

2. Do the responsibilities of IACs affect the reinforcement of the independence of internal audit services in Jordanian commercial banks?

3. Do the powers of the IACs affect the reinforcement of the independence of internal audit services in Jordanian commercial banks?

\subsection{Study Objectives}

The objective of this study aims at identifying the impact of the IACs practices on enhancing the independence of the internal audit services in the Jordanian commercial banks and thus achieving the following sub-objectives:

1. Identify the impact of the functions of the IACs on enhancing the independence of the internal audit services in the Jordanian commercial banks.

2. Identify the impact of the responsibilities of the IACs on enhancing the independence of the internal audit staff in Jordanian commercial banks.

3. Identify the impact of IACs on enhancing the independence of the internal audit staff in Jordanian commercial banks.

\subsection{Study Hypotheses}

H0: There is no impact of a statistical indication for practices of the IACs on enhancing the independence of the internal audit staffs in Jordanian commercial banks; the following sub-hypotheses are derived from:

H01: There is no impact of the functions of IACs on enhancing the independence of the internal audit staff in Jordanian commercial banks.

H02: There is no impact of the responsibilities of IACs on enhancing the independence of the internal audit staff in Jordanian commercial banks.

H03: There is no impact of the powers of IACs on enhancing the independence of the internal audit staff in Jordanian commercial banks.

\subsection{Limitations of the Study}

Perhaps the most prominent determinants of the study is the inability of the researcher to find previous studies related to the subject of the study, therefore, the researcher used the studies related to some of the study variables.

\subsection{Theoretical Background}

\subsubsection{Concept and the Importance of the Audit committees:}

The need to the existence of audit committees (ACs) has emerged to assist high management in exercising its supervisory and control functions efficiently and effectively, in addition to hinder the manipulation of executive management in the financial statements, and due to the increased interest in this concept, all countries of the world has issued a number of laws and legislations that emphasize the need for ACs within the organizational structure of companies in their various forms.

Audit committee (AC) has been defined by many researchers and bodies, (Braiotta, 2010), (Arens et al, 2010:) defined it as: "a selective number of persons among the members of the board of directors of the company, which shall be responsible for maintaining the auditor's independence from management, it may consist of three, five or seven members of non-executives of the board of directors, as Richard M. Ferry chairman of the Global Korn/ Ferry pointed out that it is "An arbitrary committee emanating from the board of directors, which is composed mainly of non-executive directors, who are characterized by independency, on contrary to the other arbitrary committees that are constituents from management board such as the finance or executive committees" (AICPA, 
1978), while (Mallin, 2003) defined it as: "A committee composed of non executives directors which is responsible for assessment of the performance of the management board and make sure that the executive decisions have been issued individually, in addition to conduct a periodical evaluation of the internal control system, also contributing in determining the missions and responsibilities for internal and external audit", while (CICA, 1992) defined as: "A committee composed of non executives' managers that their responsibilities concentrated on auditing the annual finance menus before submitting them to the management board. The audit committee is considered as a link between auditors and the management board, its activities summed up by nominating the external auditor and auditing the scope and the results of the auditing, as well as evaluating the internal control system of the company and all the published financial information".

(Marria n, 1988) defined it as: "A committee composed of three to five directors who are not responsible of any executive responsibilities of the financial management and most of its work concerns auditing financial reports, evaluating the effectiveness of the internal control and accounting system of the company, in addition to discussing the results of the auditing with the internal and external auditors and submit recommendations about nominating and identifying the fees for the external auditor".

(Sarbanes-Oxley Law, 2002) law indicated a set of requirements that must be provided in the member of the AC, such as experience and scientific qualification, in addition to the familiarity with the nature of the functions of the $\mathrm{AC}$ and its responsibilities, although there is no consensus on one and a specific definition of this committee, but there is a consensus on some special features of its composition and functions, including:

1. A committee issued from the management board and composed from non-executive members.

2. A professional committee with a high degree of experience and knowledge of accounting and auditing.

3. Conducting supervision and control on a group of internal and external parties at the company.

4. There is interference between its responsibilities towards the internal parties and it works to coordinate between those parties.

5. Aims to protect the rights of shareholders.

2.5.2 The Role of Audit Committees in Supporting the Effectiveness of Internal Audit

AC performs an important role in increasing the effectiveness of internal audit and work for its improvement and development, specially, that internal audit operations have a large impact on all operations of the company, as well as the function of internal audit is considered the most important parts of the internal control system applied at the company.

Given to the important role that is played by the internal audit function in hindering the manipulation and discovering errors, and because the internal auditors are employees inside the company and have a full acknowledge of the nature of company's operations and the applied accounting policies, many bodies concerned with the necessity of the $\mathrm{AC}$ to follow up internal audit plans and choose the appropriate party to perform the auditing and hold meeting with the head of internal audit to solve the discovered errors and solve them, (Suleiman, 2006), therefore, the AC should pay attention to the internal audit, since there is mutual relationship between them and they affect each other.

In order to accomplish the internal auditors their role effectively, they should enjoy the independency, so that the existence of AC in the company would consolidate and promote the independence of internal audit, which start with nominating a responsible auditing team and study their work plan and the scope of examination and reports which are issued by them, as well as provide the necessary resources for them and solve the problems which may arise with management and increase the interaction and coordination with the external auditor (Al-Momani 2008, p. 470), in the same context (Kevin, 2000, p. 42), sees that the first step at strengthen the independence of the internal audit is represented in that its activities should not be linked with senior management of the company, because that will decrease the confidence of users of finance statements in the audit works ability to avoid cheating, where the efficiency and objectivity of these works enhanced when hiring the internal auditors and identify their rewards and dismissing them are within the power of the $\mathrm{AC}$, and their reports should be oriented to this committee in order to study and evaluate it and raise notes and recommendations to the management board.

As for independence, it was defined by (IIA , 2001) in standard No. 1100 as: To liberate from the conditions and circumstances which threatening the capacity of internal audit or the executive director of auditing to undertake of internal audit responsibilities in a nonbiased manner, and to achieve a possible investigation degree of independence necessary for effective performance of the responsibilities of internal audit activity, furthermore, the executive director of the internal audit must have the ability to access directly without any restrictions to the senior 
management and to the board, and the resources that threatening the independency on the internal auditor level and on the level of audit tasks and on functional and organizational levels should be controlled with.

(IIA, 1999) defined internal audit as: An advisory, objective, independent and reassured activity, aims to increase the operations of the entity's revenues and improve them. The internal audit helps the entity in achieving its objectives through an organized methodology to evaluate and improve the effectiveness of the risk management, control and governance.

\subsubsection{Audit Committee Functions}

AC conducts many mission regarding supporting the function of internal audit that is represented in the following (Dahdouh, 2008, p. 270):

1. Assessment of the effectiveness of internal audit and its quality as a part of internal control system that is conducted according to professional performance standard.

2. Following the regulations and systems related to internal audit tasks and approve them.

3. Checking internal audit performance strategy and its annual plan and approve them.

4. Consolidation of the independence of the internal audit through:

a. Appointing internal audit director and dismiss him.

b. Making sure that internal audit has adequate resources to maintain its operations.

c. The freedom of the audit director to contact the AC to discuss any important issues.

d. Making sure that there are no restrictions on internal auditors when they implement their duties.

e. Participation in hiring, promoting and substitute the audit team.

5. Checking the internal audit results, in particular that which has an important influence, such as the illegal actions and weakness points in internal control.

6. Checking the vocational level for internal auditors and the extent of their competence in implementing their responsibilities.

7. Coordinating between internal and external auditors' work that lead to the improvement of communication between them and increasing the quality of audit operation and achieve integration between them.

As mentioned above, the importance of the role of the AC is obvious in supporting the Internal audit operations through the supervision of the management of internal audit and study the work plan, support the independence of audit employees and maintain the communicating lines between the management board and external audit.

\subsubsection{Audit Committee Responsibilities}

AC responsibilities include conducting basic activities, (KPMG, 2004) such as:

1. Assessment of the management procedures in determining fraud risks and prevent them, including measures which implemented by the management, and is designed for discovering any fraud and prevent it.

2. Supervision on internal control applied on the management when preparing financial reports and searching for any possibility of infringement of the management or the inappropriate use of this control.

3. Comparison of the reasonability of the financial results with the previous or expected results and conduct quarterly analysis of the main reserves.

4. Assessment of management operations and its procedures, in addition to documenting all important estimates that are used in the process of preparing financial reports.

5. Assessment of the management input and documenting it regarding processing daily records which entered periodically and the process of closing the financial reports cycle.

6. Develop a program for the staff and others to report any fraud and immoral conduct.

7. Submit other visions and guidance about implementation or strengthen measures to prevent fraud.

\subsubsection{Audit Committee Powers}

The Jordanian Banking Law issued in 2000 refers to the powers of the AC. Article (32) of the Law states as follows:

A. A committee called (Audit Committee) shall be formed in each bank by a decision of its board of directors composed of a chairman and two members elected by the Board of Directors of the Bank amongst the members 
who have no executive functions within the Bank. The Committee shall continue its work for the duration of the Board membership, and the committee shall exercise the following functions and powers:

1. Monitor the comprehensiveness extent of the external audit of the bank's work and to verify the existence of coordination between works of the external auditors in case of existing more than one auditor.

2. Review the observations contained in the reports of the Central Bank and the reports of the external auditor and follow up the actions taken thereon.

3. Study the annual internal audit plan, review the observations contained in the inspection reports and the internal audit's reports and follow up on the taken procedures.

4. Review the financial statements of the bank before presenting them to the Board of Directors, in particular, verifying the Central Bank's orders regarding the adequacy of allocations taken to meet doubtful debts and the perquisites of the securities in portfolios and expressing an opinion on the bank's non-operating debts or proposed to be considered as debt-impaired.

5. Ensure the accuracy, safety and compliance of accounting and control procedures.

6. Ensure full compliance with the laws, regulations and orders that the bank works are subjected to.

7. Study any issue presented to it by the Board of Directors of the bank or any issue which the committee deems necessary to be discussed and to express an opinion thereon.

B. The committee operates under the supervision of the Board of Directors and submits to it its reports and recommendations of the results of exercising its functions.

\section{Previous Studies}

Based on study limitations, the researcher suggested using the studies related to some of the study variables as follows.

Table 1. Previous studies

\begin{tabular}{|c|c|c|c|}
\hline Author & tudy title & Study objectives & Results \\
\hline Tamer, (2010) & $\begin{array}{l}\text { The Role of audit } \\
\text { committees } \\
\text { Consolidation of Internal } \\
\text { Auditor at Commercial } \\
\text { Banks. }\end{array}$ & $\begin{array}{l}\text { Shedding light upon the meaning of ACs } \\
\text { in terms of their formation, objectives and } \\
\text { responsibilities to increase and confirm } \\
\text { the credibility of financial statements and } \\
\text { reports. }\end{array}$ & $\begin{array}{l}\text { It found that the existence of an internal } \\
\text { committee in commercial banks will } \\
\text { consolidate the independence of internal } \\
\text { auditor and help at raise the efficiency and } \\
\text { effectiveness of internal audit management } \\
\text { performance. }\end{array}$ \\
\hline $\begin{array}{l}\text { Stewart \& } \\
\text { Subramaniam, } \\
(2009)\end{array}$ & $\begin{array}{l}\text { Internal Audit } \\
\text { Independence and } \\
\text { Objectivity: A review of } \\
\text { current literature and } \\
\text { opportunities for future. }\end{array}$ & $\begin{array}{l}\text { To reviewed the modern literatures about } \\
\text { the objectivity and independence of } \\
\text { internal audit at the current professional } \\
\text { environment. }\end{array}$ & $\begin{array}{l}\text { The independency and objectivity of internal } \\
\text { audit is a rich and fruitful field from } \\
\text { investigation, where researchers can submit a } \\
\text { valuable contribution in the continuous } \\
\text { development of the profession. }\end{array}$ \\
\hline $\begin{array}{l}\text { Christopher, } \\
\text { Sarens, and } \\
\text { Leung (2009) }\end{array}$ & $\begin{array}{l}\text { "A critical analysis of the } \\
\text { independence of the } \\
\text { internal audit function: } \\
\text { evidence from Australia". }\end{array}$ & $\begin{array}{l}\text { Aims to critically analyze the } \\
\text { independence of the internal audit } \\
\text { function through its relationship with } \\
\text { management and the AC. }\end{array}$ & $\begin{array}{l}\text { Identified a number of threats to } \\
\text { independence including having the CEO or } \\
\mathrm{CFO} \text { approve the internal audit budget and } \\
\text { being involved in the audit plan, not reporting } \\
\text { functionally to the AC, the AC not having } \\
\text { sole responsibility for appointing and } \\
\text { dismissing the CAE and a lack of AC } \\
\text { accounting expertise. }\end{array}$ \\
\hline $\begin{array}{l}\text { Van Peursem } \\
(2005)\end{array}$ & $\begin{array}{l}\text { "Conversations with } \\
\text { internal auditors: the } \\
\text { power of ambiguity". }\end{array}$ & $\begin{array}{l}\text { Examines the New Zealand internal } \\
\text { auditor role and addresses how an } \\
\text { effective internal auditor can overcome } \\
\text { the tension of working with management } \\
\text { to improve performance while also } \\
\text { remaining sufficiently distant from } \\
\text { management in order to report on their }\end{array}$ & $\begin{array}{l}\text { Found internal auditors' close relationship } \\
\text { with management can place their } \\
\text { independence from management at risk. }\end{array}$ \\
\hline
\end{tabular}




\begin{tabular}{|c|c|c|c|}
\hline $\begin{array}{l}\text { Thomas, et. al, } \\
\text { (2004) }\end{array}$ & $\begin{array}{l}\text { The Role of Audit } \\
\text { Committees at } \\
\text { Consolidation of Internal } \\
\text { Auditor at Commercial } \\
\text { Banks. }\end{array}$ & $\begin{array}{l}\text { performance. } \\
\text { To analyzing and acknowledging the } \\
\text { importance and the benefit of ACs for } \\
\text { small business banks }\end{array}$ & $\begin{array}{l}\text { The study reached out that banks which have } \\
\text { an internal audit committee have an internal } \\
\text { control more than banks that don't have such } \\
\text { internal committees. }\end{array}$ \\
\hline $\begin{array}{l}\text { Lee, Mande, and } \\
\text { Ortman, (2004) }\end{array}$ & $\begin{array}{l}\text { The impact of audit } \\
\text { committee and the board of } \\
\text { directors on the } \\
\text { independence of the } \\
\text { auditor. }\end{array}$ & $\begin{array}{l}\text { To shed the light on the impact of the ACs } \\
\text { and board of directors on the } \\
\text { independence of the auditor. }\end{array}$ & $\begin{array}{l}\text { The serious cooperation with the auditor } \\
\text { results from the independence of the ACs and } \\
\text { board of directors. }\end{array}$ \\
\hline $\begin{array}{l}\text { Keinath, et al., } \\
(2004)\end{array}$ & $\begin{array}{l}\text { Audit Committee } \\
\text { Responsibilities Focusing } \\
\text { on Oversight, Open } \\
\text { Communication, and Best } \\
\text { Practices. }\end{array}$ & $\begin{array}{l}\text { To identify the responsibilities of the AC } \\
\text { and its role in supervising the preparation } \\
\text { of financial reports. }\end{array}$ & $\begin{array}{l}\text { It found that } 100 \% \text { of the ACs are responsible } \\
\text { for reviewing the annual financial reports. }\end{array}$ \\
\hline Goodwin (2003) & $\begin{array}{l}\text { The relationship between } \\
\text { the audit committee and } \\
\text { the internal audit function: } \\
\text { Evidence from Australia } \\
\text { and New Zealand. }\end{array}$ & $\begin{array}{l}\text { Explores the separate impact of AC } \\
\text { independence and the proportion of } \\
\text { members with accounting or finance } \\
\text { experience on the AC's relations with the } \\
\text { internal audit function. It also seeks to } \\
\text { isolate differences between public and } \\
\text { private sector ACs and between Australia } \\
\text { and New Zealand. }\end{array}$ & $\begin{array}{l}\text { Found independence and accounting } \\
\text { experience have a complementary impact on } \\
\text { AC relations with internal audit. AC } \\
\text { independence was found to be more } \\
\text { associated with issues of process while } \\
\text { accounting experience is associated with AC } \\
\text { reviewing the work of internal audit. }\end{array}$ \\
\hline $\begin{array}{l}\text { Carcello, } \\
\text { Hermanson and } \\
\text { Neal (2002) }\end{array}$ & $\begin{array}{l}\text { Disclosures in audit } \\
\text { committee charters and } \\
\text { reports. }\end{array}$ & $\begin{array}{l}\text { Explores } \mathrm{AC} \text { activities and identifies } \\
\text { possible areas for further } \mathrm{AC} \text { reform. } \\
\text { Included disclosures relating to auditor } \\
\text { oversight. }\end{array}$ & $\begin{array}{l}\text { Found disclosures relating to external audit } \\
\text { were more prevalent than those relating to } \\
\text { internal audit. Less than } 50 \% \text { of companies } \\
\text { reported having private meetings with } \\
\text { internal audit. }\end{array}$ \\
\hline $\begin{array}{l}\text { Raghunandan, } \\
\text { Read and Rama } \\
\text { (2001) }\end{array}$ & $\begin{array}{l}\text { Audit } r \text { committee } \\
\text { composition, } \quad \text { gray } \\
\text { directors,' and interaction } \\
\text { with internal auditing. }\end{array}$ & $\begin{array}{l}\text { Examines the association between AC } \\
\text { composition and the committee's } \\
\text { interaction with internal audit. }\end{array}$ & $\begin{array}{l}\text { Found that ACs without 'gray' directors and at } \\
\text { least one member with financial expertise } \\
\text { will have longer meetings with the CAE } \\
\text { provide private access to the CAE, and } \\
\text { review the IA program, results and interaction } \\
\text { with management. Provides empirical } \\
\text { support that AC composition can impact on } \\
\text { oversight activities. }\end{array}$ \\
\hline $\begin{array}{l}\text { Goodwin and } \\
\text { Yeo }(2001)\end{array}$ & $\begin{array}{l}\text { Two factors affecting } \\
\text { internal audit } \\
\text { independence and } \\
\text { objectivity: Evidence from } \\
\text { Singapore. }\end{array}$ & $\begin{array}{l}\text { Examines whether the relationship } \\
\text { between internal audit and the AC } \\
\text { influences the independence and } \\
\text { objectivity of internal auditors. }\end{array}$ & $\begin{array}{l}\text { Found the level of interaction between an AC } \\
\text { and internal audit was greater when the AC } \\
\text { was comprised of independent directors. }\end{array}$ \\
\hline
\end{tabular}

\section{Data and Methodology}

This chapter describes the research methodology in this study. The chapter included the research questions and hypotheses, design of the study, population of the study, sample, and the instruments used in this study.

\subsection{Study Population}

The study population consists of the external auditors practicing auditing profession in Jordan, they are: 402 auditors from (Jordan Association of Certified Public Accountants, JACPA). In order to achieve the objectives of the study, a purposive sample of 90 auditors was selected to audit the accounts of the commercial banks in Jordan, 87 questionnaires were retrieved and thus the recovery rate was $97 \%$. 


\subsection{Demographic Data}

Table 2 shows the distribution of the sample study according to the demographic variables

Table 2. Frequency distribution of demographic data

\begin{tabular}{|c|c|c|c|}
\hline Variables & Measure & Frequency & Percentage \\
\hline \multirow{6}{*}{ Career level } & Partner & 5 & $5.7 \%$ \\
\hline & Manager & 9 & $10.3 \%$ \\
\hline & Supervisor & 23 & $26.5 \%$ \\
\hline & Senior Auditor & 42 & $48.2 \%$ \\
\hline & Junior Auditor & 8 & $9.3 \%$ \\
\hline & Total & 87 & $100.0 \%$ \\
\hline \multirow{5}{*}{ Qualification } & Ph.D. & 3 & $3.5 \%$ \\
\hline & Master & 28 & $32.2 \%$ \\
\hline & Bachelor & 56 & $64.3 \%$ \\
\hline & Total & 87 & $100.0 \%$ \\
\hline & Accountancy & 67 & $77 \%$ \\
\hline \multirow{3}{*}{ Specialization } & Finance and Banking & 9 & $10.3 \%$ \\
\hline & Finance Management & 11 & $12.7 \%$ \\
\hline & Total & 87 & $100.0 \%$ \\
\hline \multirow{5}{*}{ Experience } & Less than 5 years & 4 & $4.6 \%$ \\
\hline & From 5 to $<10$ & 17 & $19.5 \%$ \\
\hline & From 10 to $<15$ & 36 & $41.4 \%$ \\
\hline & More than 15 & 30 & $34.5 \%$ \\
\hline & Total & 87 & $100.0 \%$ \\
\hline \multirow{5}{*}{ Age } & Less than 30 years & 7 & $8 \%$ \\
\hline & From 30 to 40 & 23 & $26.4 \%$ \\
\hline & From $41-50$ & 44 & $50.6 \%$ \\
\hline & More than 50 & 13 & $15 \%$ \\
\hline & Total & 87 & $100.0 \%$ \\
\hline
\end{tabular}

\subsection{Study Tools}

Researcher designed questionnaire to gather primary data from external auditors after returning to the theoretical literature, and earlier studies related.

The survey consisted of (46) item represented the study variables, all items of the questionnaire were measured by a 5 -point Likert scale with anchors ranging from $1=$ strongly disagree to $5=$ strongly agree.

Then the cells have been identified along the five Likert scale (lower and upper limits) as follows:

- $\quad$ Arithmetic average was considered normal (default) is the answer (3) and represents a "neutral."

- The term has been calculated according to the following equation: higher weight minus the lowest weight range $=\leftarrow(5-1=4)$

- The division averages for answers to five degrees represent a degree of agreement (strongly agree, agree, neutral, disagree, and strongly disagree).

- The length of the cell was calculated according to the following equation: Range $\div$ number of levels $=$ length of the cell $4 \div 3=1.33$

- Added value of the length of the cell (1.33) to the beginning of the scale (the lowest value in the scale, namely, (1) to determine the upper limit for the first cell, and thus becomes the length of the cells as shown in Table 3.

Table 3. The length of the cells five Likert scale

\begin{tabular}{ll}
\hline Categories & Relative Importance \\
\hline From (1.00) to less than (2.33) & Low \\
From (2.33) to less than (3.66) & Moderate \\
From (3.66) to (5.00) & High \\
\hline
\end{tabular}




\subsection{Statistical Treatment}

The study has analyzed collected data via Statistical Package for the Social Sciences (SPSS) and to achieve the objectives of this study as follows:

1. Frequencies and percentages: where it was used to describe the social data for the study sample of respondents.

2. Arithmetic average and standard deviation: where they were used to judge the response of the study sample on the variables of the study.

3. Cronbach alpha reliability coefficient and factor analysis in order to verify the reliability and validity of research tool.

4. Multiple regression method: To measure the effect of the relationship between more than one independent variable and the dependent variable.

5. Stepwise regression method: To compare the change in explanatory power of models by adding variables, in order to determine which variable.

\subsection{Reliability Tests}

To test the reliability of study tool, Cronbach's Alpha was used and the results revealed a Cronbach's alpha coefficient was $(0.848)$ for all items, and values of $(\alpha)$ range $(0.743$ to 0.825$)$, which refers the questionnaire is reliable. The values of $(\alpha)$ of the study variables of the study were as in Table 4 .

Table 4. Reliability tests and data summary

\begin{tabular}{llr}
\hline Variable & No. of Items & Reliability Coefficient $(\boldsymbol{\alpha})$ \\
\hline Audit Committee Functions & 12 & 0.781 \\
Audit Committee Responsibilities & 10 & 0.743 \\
Audit Committee Powers & 12 & 0.785 \\
Audit Committees' Practices & 34 & 0.825 \\
Enhancing the Independence of Internal Audit & 12 & 0.762 \\
General rate & $\mathbf{4 6}$ & 0.848 \\
\hline
\end{tabular}

\subsection{Analysis of the Responses of the Study Sample Members}

The responses of the sample were presented using statistical descriptive measures; the arithmetic means, standard deviations, grade and materiality were calculated.

First: Internal Audit Committee Practices, including:

\section{Functions of the Audit Committee}

Table 5. The arithmetic means, standard deviations and the materiality of the Audit Committee's functions:

\begin{tabular}{|c|c|c|c|c|c|}
\hline $\begin{array}{l}\text { Item } \\
\text { No. }\end{array}$ & Paragraph & Means & Std. Dev. & $\begin{array}{l}\text { Relative } \\
\text { Important }\end{array}$ & Rank \\
\hline 1 & $\begin{array}{l}\text { To ensure that the audit committees evaluate the effectiveness and } \\
\text { quality of the internal audit in accordance with the standards of } \\
\text { professional performance. }\end{array}$ & 3.862 & 0.891 & High & 5 \\
\hline 2 & $\begin{array}{l}\text { To ensure that the audit committees follow the rules and regulations } \\
\text { related to internal audit functions and approve them. }\end{array}$ & 3.770 & 0.859 & High & 10 \\
\hline 3 & $\begin{array}{l}\text { To ensure that the audit committees check and examine the } \\
\text { performance strategy of the internal audit and the annual plan and } \\
\text { approve them. }\end{array}$ & 3.842 & 0.901 & High & 7 \\
\hline 4 & $\begin{array}{l}\text { To ensure that the audit committees are acquainted with the task of } \\
\text { strengthening the independence of the internal audit regarding the } \\
\text { appointment of audit director and dismissing him. }\end{array}$ & 3.897 & 0.928 & High & 3 \\
\hline 5 & $\begin{array}{l}\text { To ensure that the audit committees are acquainted with the function } \\
\text { of strengthening the independence of internal audit to verify the } \\
\text { adequacy of human resources to perform the activity. }\end{array}$ & 3.874 & 0.938 & High & 4 \\
\hline
\end{tabular}




\begin{tabular}{|c|c|c|c|c|c|}
\hline 6 & $\begin{array}{l}\text { To ensure that the Audit Director has the freedom to contact directly } \\
\text { with the Audit Committees to discuss important issues. }\end{array}$ & 3.782 & 0.933 & High & 9 \\
\hline 7 & $\begin{array}{l}\text { To ensure that there are no restrictions on auditors when performing } \\
\text { their duties. }\end{array}$ & 3.690 & 0.853 & High & 12 \\
\hline 8 & $\begin{array}{l}\text { To ensure that the audit committees participate in the appointment, } \\
\text { promotion and replacement of internal audit teams. }\end{array}$ & 3.851 & 0.909 & High & 6 \\
\hline 9 & $\begin{array}{l}\text { To ensure that the audit committees check the results of the internal } \\
\text { audit that has a legal effect. }\end{array}$ & 4.103 & 0.836 & High & 1 \\
\hline 10 & $\begin{array}{l}\text { To ensure that the audit committees examine the internal control } \\
\text { system to determine their weaknesses. }\end{array}$ & 4.011 & 0.883 & High & 2 \\
\hline 11 & $\begin{array}{l}\text { To ensure that there is coordination and communication between } \\
\text { internal and external auditors to achieve complementarily and } \\
\text { increase the quality of the audit process. }\end{array}$ & 3.713 & 0.834 & High & 11 \\
\hline 12 & $\begin{array}{l}\text { To ensure that the audit committees are encouraged to strengthen the } \\
\text { independence of the internal audit teams. }\end{array}$ & 3.836 & 0.938 & High & 8 \\
\hline \multicolumn{2}{|c|}{ General average } & 3.852 & 0.829 & High & \\
\hline
\end{tabular}

We note from table 5 that the overall scale of the functions of the Audit Committee is high, where the overall average reached (3.852) with a standard deviation of (0.829), the paragraph (To be sure that audit committees will examine the internal audit findings that have legal effect) ranked first with an arithmetic mean of (4.103) and with a high relative significance, while the paragraph (To be sure that there are no restrictions on auditors in carrying out their duties) was in the last rank with an arithmetic mean of (3.690) and with a high materiality.

\section{Responsibilities of the Audit Committee}

Table 6. The arithmetic means, standard deviations and the materiality of the Audit Committee's responsibilities paragraphs

\begin{tabular}{|c|c|c|c|c|c|}
\hline $\begin{array}{l}\text { Item } \\
\text { No. }\end{array}$ & Paragraph & Means & Std. Dev. & $\begin{array}{l}\text { Relative } \\
\text { Important }\end{array}$ & Rank \\
\hline 13 & $\begin{array}{l}\text { The external auditor considers the procedures of the bank's } \\
\text { management in identifying and reducing the risks of fraud. }\end{array}$ & 3.920 & 0.750 & High & 4 \\
\hline 14 & $\begin{array}{l}\text { The external auditor takes into account the bank's procedures to help } \\
\text { detect and reduce fraud. }\end{array}$ & 3.954 & 0.791 & High & 2 \\
\hline 15 & $\begin{array}{l}\text { To ensure that the audit committees supervise the internal control } \\
\text { system applied by the bank. }\end{array}$ & 3.885 & 0.722 & High & 5 \\
\hline 16 & $\begin{array}{l}\text { To ensure checking of any possible misuse or infringement of the } \\
\text { control system by the bank's management. }\end{array}$ & 3.816 & 0.724 & High & 8 \\
\hline 17 & $\begin{array}{l}\text { Comparisons of current financial results with previous, prospective } \\
\text { and expected results are reviewed. }\end{array}$ & 4.023 & 0.792 & High & 1 \\
\hline 18 & $\begin{array}{l}\text { To ensure that the audit committees conduct a quarterly analysis of } \\
\text { the main reserves. }\end{array}$ & 3.828 & 0.735 & High & 7 \\
\hline 19 & $\begin{array}{l}\text { Management procedures are reviewed and documented for all } \\
\text { significant estimates used in the financial reporting. }\end{array}$ & 3.805 & 0.713 & High & 9 \\
\hline 20 & $\begin{array}{l}\text { The assessment and documentation of management input are } \\
\text { examined with respect to the manual handling of daily entries and } \\
\text { the closure process. }\end{array}$ & 3.839 & 0.745 & High & 6 \\
\hline 21 & $\begin{array}{l}\text { To ensure that audit committees develop a program for the staff and } \\
\text { auditors about fraud and immoral conduct. }\end{array}$ & 3.713 & 0.746 & High & 10 \\
\hline 22 & $\begin{array}{l}\text { Audit committees are encouraged to see other insights and guidance } \\
\text { concerning implementing or strengthening fraud reduction } \\
\text { measures. }\end{array}$ & 3.931 & 0.744 & High & 3 \\
\hline \multicolumn{2}{|c|}{ General average } & 3.871 & 0.702 & High & \\
\hline
\end{tabular}

We note from table 6 that the overall scale of the responsibilities of the Audit Committee is high, where the overall mean was (3.871) with a standard deviation of (0.702),the paragraph (To be acquainted with the 
comparisons of current financial results with the previous, subsequent and expected results) ranked first with a mean of (4.023) and with a high relative significance, while the paragraph (To be sure that the audit committees have established programs for staff and auditors to report on fraud and immoral behavior) ranked last with a mean of (3.713) and with a high relative significance.

\section{The Powers of the Audit Committee}

Table 7. The arithmetic means, standard deviations and materiality of the powers of the audit committee paragraphs

\begin{tabular}{|c|c|c|c|c|c|}
\hline $\begin{array}{l}\text { Item } \\
\text { No. }\end{array}$ & Paragraph & Means & Std. Dev. & $\begin{array}{l}\text { Relative } \\
\text { Important }\end{array}$ & Rank \\
\hline 23 & $\begin{array}{l}\text { To ensure that the audit committees monitor the extent of } \\
\text { comprehensiveness of the external audit of the bank's work. }\end{array}$ & 3.816 & 0.815 & High & 8 \\
\hline 24 & $\begin{array}{l}\text { To ensure that the audit committees verify the existence of } \\
\text { coordination between the work of internal and external audit in case } \\
\text { of more than one external auditor. }\end{array}$ & 3.609 & 0.812 & Moderate & 11 \\
\hline 25 & $\begin{array}{l}\text { To ensure that the audit committees review the observations } \\
\text { contained in the reports of the Central Bank, the external auditor and } \\
\text { the procedures taken. }\end{array}$ & 3.552 & 0.759 & Moderate & 12 \\
\hline 26 & $\begin{array}{l}\text { To ensure that the audit committees study the annual internal audit } \\
\text { plan and review the observations contained in the inspection reports } \\
\text { and internal audit reports. }\end{array}$ & 3.897 & 0.807 & High & 6 \\
\hline 27 & $\begin{array}{l}\text { To ensure that the audit committees review the financial statements } \\
\text { of the bank before presenting them to the Board of Directors. }\end{array}$ & 3.945 & 0.798 & High & 4 \\
\hline 28 & $\begin{array}{l}\text { To ensure that the audit committees check that the bank is complying } \\
\text { with the policy of the Central Bank's provisions regarding adequacy } \\
\text { of provisions. }\end{array}$ & 3.989 & 0.755 & High & 2 \\
\hline 29 & $\begin{array}{l}\text { To ensure that the audit committees verify the existence of } \\
\text { non-performing debts or impaired debts. }\end{array}$ & 4.034 & 0.813 & High & 1 \\
\hline 30 & $\begin{array}{l}\text { To ensure that the audit committees verify the accuracy and integrity } \\
\text { of the accounting and control procedures and their compliance. }\end{array}$ & 3.941 & 0.854 & High & 5 \\
\hline 31 & $\begin{array}{l}\text { To ensure that the audit committees shall comply with the laws, } \\
\text { regulations and orders to which the Bank's business is subject. }\end{array}$ & 3.966 & 0.769 & High & 3 \\
\hline 32 & $\begin{array}{l}\text { To ensure that the audit committees to study the issues presented to } \\
\text { them by the Board of Directors. }\end{array}$ & 3.713 & 0.761 & High & 10 \\
\hline 33 & $\begin{array}{l}\text { To ensure that the audit committees express their opinion on any } \\
\text { unusual transaction or issue. }\end{array}$ & 3.747 & 0.810 & High & 9 \\
\hline 34 & $\begin{array}{l}\text { To ensure that the work of the audit committee is carried out under } \\
\text { the supervision of the Board of Directors and submits the reports and } \\
\text { recommendations of the results of practicing its powers to the Board. }\end{array}$ & 3.828 & 0.810 & High & 7 \\
\hline \multicolumn{2}{|c|}{ General average } & 3.836 & 0.731 & High & \\
\hline
\end{tabular}

We note from table 7: That the general measure level of the paragraphs of the powers of the ACs is high, where the arithmetic mean had reached(3.836) with a standard deviation of (0.731), the paragraph (To be sure that ACs will verify the existence of the non - functioning debt or bad debt) was in the first rank with an arithmetic mean of (4.034) with high relative significance, while the paragraph (To be sure that the ACs review the observations contained in the reports of the Central Bank, the external auditor and the measures taken thereon) was at the last rank with arithmetic mean of (3.552) and with an average materiality.

To compare the practices of internal ACs, the following table was prepared: 
Table 8. To calculate arithmetical means, standard deviations and overall materiality

\begin{tabular}{llllll}
\hline Item No. & Paragraph & Means & Std. Dev. & Relative Important & Rank \\
\hline 1 & Audit Committee Functions & 3.852 & 0.829 & High & 2 \\
2 & Audit Committee Responsibilities & 3.871 & 0.702 & High & 1 \\
3 & Audit Committee Powers & 3.836 & 0.731 & High & 3 \\
& Audit Committees' Practices & $\mathbf{3 . 8 5 3}$ & $\mathbf{0 . 5 8 7}$ & High & \\
\hline
\end{tabular}

The results of table 8 indicates that the level of internal audit committees' practices in terms of materiality is high, the arithmetic mean reached (3.853) with a standard deviation of (0.587), also the table showed that (the responsibilities of the Audit Committee) came in the first rank with an arithmetic mean of (3.871) and a standard deviation of (0.702), with a high relative significance, while (the powers of the audit committee) ranked last with an arithmetic mean of (3.836) and standard deviation of (0.731), with a high materiality.

\section{Second: Independency of Internal Audit}

Table 9. The arithmetic means, standard deviations and materiality of the independency of internal audit paragraphs

\begin{tabular}{|c|c|c|c|c|c|}
\hline $\begin{array}{l}\text { Item } \\
\text { No. }\end{array}$ & Paragraph & Means & Std. Dev. & $\begin{array}{l}\text { Relative } \\
\text { Important }\end{array}$ & Rank \\
\hline 35 & $\begin{array}{l}\text { The appointment of internal auditors by the Board of Directors and } \\
\text { not by the bank's executive management shall enhance the } \\
\text { independence of internal audit. }\end{array}$ & 3.874 & 0.950 & High & 9 \\
\hline 36 & $\begin{array}{l}\text { Linking the activities of the bank's executive management with } \\
\text { internal auditors will enhance the independence of internal audit. }\end{array}$ & 3.989 & 0.896 & High & 2 \\
\hline 37 & $\begin{array}{l}\text { The confidence of users of financial statements in fraud prevention } \\
\text { procedures will enhance the independence of internal audit. }\end{array}$ & 3.690 & 0.767 & High & 12 \\
\hline 38 & $\begin{array}{l}\text { The appointment of qualified and experienced auditors will enhance } \\
\text { the independence of internal audit. }\end{array}$ & 3.920 & 0.866 & High & 5 \\
\hline 39 & $\begin{array}{l}\text { The internal auditors' avoidance of the pressures that may be } \\
\text { exercised by the bank's management will enhance the independency } \\
\text { of the internal audit. }\end{array}$ & 3.954 & 0.888 & High & 4 \\
\hline 40 & $\begin{array}{l}\text { The quality of internal audit reports contributes to enhancing the } \\
\text { independence of internal audit. }\end{array}$ & 4.011 & 0.883 & High & 1 \\
\hline 41 & $\begin{array}{l}\text { Adherence to by-laws, regulations and standards of professional and } \\
\text { ethical performance will increase the level of internal audit } \\
\text { independency. }\end{array}$ & 3.759 & 0.862 & High & 11 \\
\hline 42 & $\begin{array}{l}\text { Knowledge of international accounting standards and generally } \\
\text { accepted principles will enhance the independence of internal audit. }\end{array}$ & 3.770 & 0.803 & High & 10 \\
\hline 43 & $\begin{array}{l}\text { Direct and ongoing supervision by the internal audit manager on } \\
\text { internal control systems will contribute to enhance the independence } \\
\text { of internal audit. }\end{array}$ & 3.885 & 0.945 & High & 8 \\
\hline 44 & $\begin{array}{l}\text { Periodic review of the bank's operational operations will enhance the } \\
\text { independence of internal audit. }\end{array}$ & 3.897 & 0.778 & High & 7 \\
\hline 45 & $\begin{array}{l}\text { Compliance with governance guidelines and Basel Committee } \\
\text { requirements will contribute in enhancing internal audit } \\
\text { independence. }\end{array}$ & 3.966 & 0.908 & High & 3 \\
\hline 46 & $\begin{array}{l}\text { Delegating or granting some of the powers of the Audit Manager to } \\
\text { the Audit Team contribute in enhancing the independence of internal } \\
\text { audit. }\end{array}$ & 3.908 & 0.858 & High & 6 \\
\hline \multicolumn{2}{|c|}{ General average } & 3.885 & 0.808 & High & \\
\hline
\end{tabular}

We note from table 9 that the general measure of the independency of internal audit level paragraphs is high, where the arithmetic mean reached (3.885) with a standard deviation of (0.808), the paragraph stated that(The degree of quality of internal audit reports contribute in strengthening the independency of the internal audit) ranked first with an arithmetic mean of (4.011) and with a high relative significance, while the paragraph (The confidence of users 
of financial statements in fraud prevention and fraud procedures will enhance the independence of internal audit) ranked last with an arithmetic mean of (3.690) and with high materiality.

\subsection{Test the Hypotheses of The Study}

The main hypothesis of the study was tested using multiple regression analysis; and the following is the results of testing hypothesis:

\subsubsection{The Major Hypothesis}

H0: There is no statistically significant impact of the internal audit committees' practices on the independence of internal audit services in the Jordanian commercial banks.

Table10. Examine the Impact of Internal ACs practices on enhancing the independence of internal audit

\begin{tabular}{|c|c|c|c|c|c|c|}
\hline \multirow[b]{2}{*}{ The Dependent Variable } & \multicolumn{3}{|c|}{ Sample Summary } & \multicolumn{3}{|c|}{ Analysis of Variance ANOVA } \\
\hline & $\mathrm{R}$ & $\mathrm{R}^{2}$ & Adj. $R^{2}$ & $\begin{array}{l}\text { The Calculated } \\
\text { of } F\end{array}$ & Values & $\operatorname{Sig}(F)$ \\
\hline Enhancing the Independence of Internal Audit & 0.715 & 0.511 & 0.492 & & 40.258 & 0.000 \\
\hline
\end{tabular}

Table 10 shows the existence of moral effect of (practices of internal ACs) approved to (enhance the independence of internal audit), where the value of $(\mathrm{F}=40.258)$ at significant level of $(\mathrm{SigF}=0.000)$ which is less than $(0.05)$, the value of correlation coefficient $(\mathrm{R}=0.715)$ indicated the strength of the relationship between the independent variables and the dependent variable, the value of coefficient of determination $\left(\mathrm{R}^{2}=0.511\right)$ also indicated that a ratio of (51.1\%)of variance in (internal audit independency) can be explained by the variance in the (internal ACs practices) combined together, with any other factors remaining constant.

Therefore, we reject the main nihilism study hypothesis and accept the alternative hypothesis which is stated:

"There is a statistically significant impact on the practices of internal ACs on the independence of internal audit services in the Jordanian commercial banks".

Table 11. Regression Coefficient for the Impact of Internal ACs practices on enhancing the independence of internal auditing

\begin{tabular}{llllll}
\hline $\begin{array}{l}\text { Regression Coefficients } \\
\text { Independent Variables }\end{array}$ & Coefficients (B) & Standard Error & Calculated T Values & Sig (T) & VIF \\
\hline AC Functions & 0.276 & 0.071 & 3.876 & 0.000 & 1.107 \\
AC Responsibilities & 0.437 & 0.100 & 4.388 & 0.000 & 1.257 \\
AC Powers & 0.293 & 0.085 & 3.447 & 0.001 & 1.157 \\
Fixed Regression & 0.027 & 0.427 & 0.063 & 0.950 \\
\hline
\end{tabular}

Test H01: There is no impact of the functions of the internal audit committees on enhancing the level of independence of the internal audit services in the Jordanian commercial banks.

We note from table (10) above, that the regression coefficients indicated that the value of the coefficient of (internal ACs functions) reached $(\mathrm{B}=0.276)$, which is a significant impact, where the value of $(\mathrm{t})$ is $(3.876)$ and at a significant level of $(\mathrm{Sig}=0.000)$, therefore we reject the first hypothesis and accept the alternative one, which states that:

"There is an impact of the functions of the internal ACs on enhancing the level of independency of internal audit services in the Jordanian commercial banks".

Test H02: There is no impact of the responsibilities of the internal ACs on enhancing the level of independency of the internal audit services in the Jordanian commercial banks.

We note from table (10) above, that the regression coefficients indicated that the value of the coefficient at (internal ACs responsibilities) reached $(B=0.437)$, which is a significant impact, where the value of $(t)$ has reached (4.388) at a significant level of $(\mathrm{Sig}=0.000)$, therefore we reject the second hypothesis, and accept the alternative one, which states that:

"There is an impact of the responsibilities of internal ACs on enhancing the level of independence of the internal audit services in Jordanian commercial banks". 
Test H03: There is no impact on the powers of the internal ACs on enhancing the level of independency of the internal audit services in the Jordanian commercial banks.

We note from table (10) above, we note that regression coefficients indicated that the value of coefficient at (internal AC powers) reached ( $\mathrm{B}=0.293)$, which is a significant impact, where the value of $(\mathrm{t})$ has reached (3.447) at a significant level of $(\mathrm{Sig}=0.001)$, therefore we reject the third hypothesis, and accept the alternative one which states that:

"There is an impact of the powers of internal ACs in enhancing the level of independency of the internal audit services in the Jordanian commercial banks".

To demonstrate which of the internal ACs practices had the most significant impact on enhancing the independence of the internal audit bodies, a stepwise regression analysis was performed, and the results were as follows:

Table12. Results of stepwise regression analysis for the main hypothesis

\begin{tabular}{|c|c|c|c|c|c|c|c|}
\hline Model & $\begin{array}{l}\text { Enhancing the } \\
\text { Independency of Internal } \\
\text { Auditing }\end{array}$ & B & $\begin{array}{l}\text { Calculated } \\
\text { (T) Value }\end{array}$ & Sig * & $\left(\mathbf{R}^{2}\right)$ & $\begin{array}{l}\text { Calculated } \\
\text { (F)Value }\end{array}$ & Sig * \\
\hline First & AC Responsibilities & 0.671 & 6.602 & 0.000 & 0.344 & 43.588 & 0.000 \\
\hline \multirow{3}{*}{ Second } & AC Responsibilities & 0.556 & 5.590 & 0.000 & \multirow{3}{*}{0.439} & \multirow{3}{*}{32.051} & \multirow{3}{*}{0.000} \\
\hline & AC Functions & 0.282 & 3.714 & 0.000 & & & \\
\hline & AC Responsibilities & 0.437 & 4.388 & 0.000 & & & \\
\hline \multirow[t]{2}{*}{ Third } & AC Functions & 0.276 & 3.876 & 0.000 & 0.511 & 28.163 & 0.000 \\
\hline & AC Powers & 0.293 & 3.447 & 0.001 & & & \\
\hline
\end{tabular}

* The effect is statistically significant at level $(\alpha \leq 0.0 .05)$.

The results of the regression analysis show the order of entry of variables in the regression model, which represents the impact of internal ACs practices on enhancing the independence of the internal audit. It was found that (the responsibilities of internal ACs) ranked first with (34.4\%) of the dependable variance (independency of internal audit), and when adding the dimension of (The functions of internal ACs) in the second model, the proportion of interpretation increased to $(43.9 \%)$,and it was increased to $(51.1 \%)$ when we add(the powers of committees of internal audit), it was also found that the impact of the variables had a significant impact at a level of significance less than $(0.05)$.

\section{Conclusion}

Through testing hypothesis, the study found the following results:

1. There is a statistically significant impact of the internal ACs practices on enhancing the independence of the internal audit bodies in the Jordanian commercial banks.

2. The responsibilities of the ACs have had the most importantly impact in enhancing the independence of the internal audit bodies, followed by the impact of the functions of the internal ACs, while the powers of the audit committees came in last.

3. The relative importance of the variables of the study was: The responsibilities of the ACs, the functions of the ACs, the powers of the ACs.

\subsection{Recommendations}

Based on the results of the study, the researcher recommends the following:

1. The need to enact and amend laws to ensure that the ACs have full powers to supervise all matters related to the internal audit bodies in order to enhance their independence.

2. ACs needs to take further action to strengthen its responsibilities and functions with a view to enhancing the independence of the internal audit bodies.

3. Urge researchers to conduct further research on audit committee practices in the industrial, commercial and service sectors. 


\section{References}

American Institute of Certified Public Accountants. (AICPA, 1978). Audit Committees, Answer to Typical Question about Their Organization and Operating, New York. P11.

Arens, A. A., Elder, R. J., \& Mark, S. B. (2010). Auditing and Assurance Services: An Integrated Approach (10th ed.).

Braiotta, L. (2010). The audit committee handbook (5th ed.). John Wiley \& Sons, USA, p 24.

Carcello, J. V., D. R. Hermanson, \& Neal, T. L. (2002). Disclosures in audit committee charters and reports. Accounting Horizons, 16(4), 291-304. https://doi.org/10.2308/acch.2002.16.4.291

Chris, M. (2003). The Relationship between Corporate Governance, Transparency and Financial Disclousue, Selected issues in corporate governance: regional and country experiences, United Nations conference on Trade and Development, New York.

Christopher, J., Sarens, G., \& Leung, P. (2009). A critical analysis of the independence of the internal audit function: evidence from Australia. Accounting, Auditing and Accountability Journal, 22(2), 200-220. https://doi.org/10.1108/09513570910933942

Dahdouh, H. (2008). The Role of the Audit Committee in Improving the Efficiency and Effectiveness of Internal Control Systems in Companies, (Field Study). Journal of Damascus University for Economic and Legal Sciences, 24(1), 249-283.

Goodwin, J. (2003). The relationship between the audit committee and the internal audit function: Evidence from Australia and New Zealand. International Journal of Auditing, 7, 263-278. https://doi.org/10.1046/j.1099-1123.2003.00074.x

Goodwin, J., \& Yeo, T. Y. (2001). Two factors affecting internal audit independence and objectivity: Evidence from Singapore. International Journal of Auditing, 5, 107-125.

Institute of Internal Auditors (IIA). (1999). Definition of Internal Auditing. Retrieved from http://www.theiia.org/guidance/standards-and-practices/professional-practicesframework/definition-of-inter nal-auditing

Institute of Internal Auditors (IIA). (2001). Independence and Objectivity: A Framework for Internal Auditors. The Institute of Internal Auditors: Altamonte Springs, FL.

Jordan Association of Certified Public Accounting. (JACPA). Retrieved from http://jacpa.org.jo

Jordanian Banking Law. (2000). Central Bank of Jordan. Retrieved from http://www.cbj.gov.jo

Keinath, A. K., Judith, C., \& Walo, N. (2004). Audit Committee Responsibilities Focusing on Oversight, Open Communication, and Best Practices. CPA Journal.

Kevin, L. J. (2000). The Effects of Internal Audit Outsourcing on Financial Statement Users Confidence in Their Protection from Fraudulent Financial Reporting. Unpublished Doctoral Dissertation, the University Of Tennessee, Knoxville, USA.

Lee, H. Y., \& Mande, V., \& Ortman, R. (2004). The effect of audit committee and board of director in dependence on auditor resignation. Auditing a Journal of Practice and Theory, 23(2), 131-146. https://doi.org/10.2308/aud.2004.23.2.131

Marrian, I, F. (1988). Audit Committee, Edinburgh, the Institute of Chartered Accountants of Scotland.

Momani, M. A. (2008). Evaluating the controls of the composition of the audit committees and their working mechanisms in Jordanian joint stock companies to enhance corporate governance, First Scientific Conference, Faculty of Economics, University of Damascus.

Raghunandan, K., Read, W. J., \& Rama, D. V. (2001). Audit committee composition, 'gray directors,' and interaction with internal auditing. Accounting Horizons, 15(2), 105-118. https://doi.org/10.2308/acch.2001.15.2.105

Sarbanes, P., \& Oxley, M. (2013). Sarbanes-Oxley Act of 2002 the Public.

Sekaran, U., \& Bougie, R. (2010). Research methods for business: A skill-building approach (5th ed.). Haddington: John Wiley \& Sons.

Stewart, J., \& Subramaniam, N. (2009). Internal audit independence and objectivity: A review of current literature and opportunities for future research. https://www.researchgate.net/publication/241758765 
Suleiman, M. M. (2006). Corporate governance and its role in dealing with financial and administrative corruption. University House, Egypt.

Tamer, E. W. (2010). The role of audit committees in strengthening the independence of the internal auditor in commercial banks. Retrieved from https://www.aliahmedali.com

Tomas, G. N., Dave, L., \& Nichols, D. (2004). Flesher "Audit Committee Effectiveness in the Banking Industry". Management Accounting Quarterly, 5(3).

Van, P. K. (2005). Conversations with internal auditors: The power of ambiguity. Managerial Auditing Journal, 20(5), 489-512. https://doi.org/10.1108/02686900510598849

\section{Copyrights}

Copyright for this article is retained by the author(s), with first publication rights granted to the journal.

This is an open-access article distributed under the terms and conditions of the Creative Commons Attribution license (http://creativecommons.org/licenses/by/4.0/). 